\title{
Reproductive aspects of the male jaguar (Panthera onca): A review
}

\author{
López-Pérez, Elvia $^{1}$; Cortés-Villavicencio, Fernando $^{2}$; Muñoz-García, Ganuto ${ }^{3}$; \\ Gallegos-Sánchez, Jaime ${ }^{3}$; Ávalos-Rodríguez, Alejandro ${ }^{*}$ \\ 1 Universidad Autónoma Chapingo. Departamento de Zootecnia. Carretera México-Texcoco km 38.5, \\ Chapingo, Texcoco, Estado de México, México. C. P. 56230. \\ 2 Bio Animal Wild. Lerma, Estado de México, México. C. P. 52000. \\ 3 Colegio de Postgraduados Campus Montecillo. Carretera México-Texcoco km 36.5, Montecillo, Texcoco, \\ Estado de México, México. C. P. 56230. \\ 4 Universidad Autónoma Metropolitana Xochimilco. Calzada del Hueso No. 1100, Villa Quietud, Coyoacán, \\ CDMX, México. C. P. 04960. \\ * Correspondence: avalosr@correo.xoc.uam.mx
}

Gitation: López-Pérez, E., CortésVillavicencio, F., Muñoz-García, C., Gallegos-Sánchez, J., \& ÁvalosRodríguez, A. (2021). Reproductive aspects of the male jaguar (Panthera onca): A review. Agro Productividad. https://doi.org/10.32854/agrop. v14i8.2070

Editor in Chief: Dr. Jorge Cadena Iñiguez

Received: March 18, 2021. Accepted: August 24, 2021.

Published on-line: October 12, 2021

\section{ABSTRACT}

Objective: To describe the anatomy, morphology and physiology of the reproductive system of male jaguars, as well as assisted reproduction techniques.

Methodology: A literature review on the anatomy and morphology of the jaguar's reproductive system, its physiological characteristics and assisted reproduction techniques were carried out to document relevant information on the topic.

Results: With this review, basic aspects of the morphology of the reproductive system of the jaguars are disclosed, although scarce knowledge is available on their reproduction. The advances in the collection, evaluation and cryopreservation of semen of this feline are shown, in addition to assisted reproduction techniques such as artificial insemination and in vitro fertilization, which have a great potential to safeguard the species.

Study limitations: The jaguar, an emblematic species of Latinamerica, is an endangered species, like other wild felids species as ocelot (Leopardus pardalis) and margay (Leopardus wiedii), which makes it necessary to have a national assisted reproduction program. However, for this to be possible, information about their reproductive physiology is necessary, which is complicated in wild animals and even more so because the reproductive mechanisms greatly differ between felids species. There is scarce information in this regard from its free-living or Mexican zoos, it is for this reason necessary to generate such information.

Conclusions: It is necessary to continue working on designing protocols for artificial insemination and other assisted reproduction techniques such as in-vitro fertilization specifically for male Panthera onca.

Keywords: semen; free-living felids; physiology; reproduction.
This work is licensed under a

Creative Commons Attribution-NonCommercial 4.0 International license.

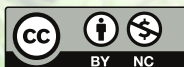




\section{INTRODUCTION}

Within an ecosystem, felines are of great importance because they are predators and help to keep it in balance; however, many of them are in danger of extinction due to habitat loss and poaching. Six of the 36 reported species of the Felidae family that existing worldwide distribute in Mexico (Ceballos and Oliva, 2005); among them, the jaguar, an emblematic species for Latin America. According to PROFEPA (2016), among the members of the Felidae family, the jaguar (Panthera onca), the ocelot (Leopardus pardalis) and the margay (Leopardus wiedii) are in endangered status, while the jaguarundi (Herpailurus yagouaroundi) is in the threatened category. This unfavorable situation raises the importance of a national assisted feline reproduction program. For this to be possible, information about their reproductive characteristics is necessary, which is complicated in the case of free-living animals and even more so because the reproductive mechanisms greatly differ between species. Therefore, information must be generated for each of them (Roldan, 2010). In addition, it would be prudent to use assisted reproduction techniques generated for other mammals. According to the Yaguareté network in Argentina (http://www.redyaguarete. org.ar/el-yaguarete/celo-y-reproduccion/), there is no specific reproductive season for jaguars, although it is noted that they give birth during spring in extreme climates, which could be due to greater prey availability; and at any time in tropical areas, since light and humidity remain constant throughout the year. In the case of Mexico, Ceballos $e t$ al. (2011) mention that the jaguar's reproductive season occurs between December and January. Knowledge regards the jaguar's reproduction will allow a better understanding of the mechanisms involved in its occurrence. Therefore, the objective of this review was to describe the anatomy, morphology and physiology of the jaguar's reproductive system, as well as assisted reproduction techniques in this species.

\section{REPRODUGTION}

\section{Anatomy of the reproductive system}

The reproductive apparatus of the jaguar consists of a penis and testes. The penis is conical and located within a prepuce; when animals are not sexually active, it is caudally oriented, however, during coitus the position is reversed (Figure 1).
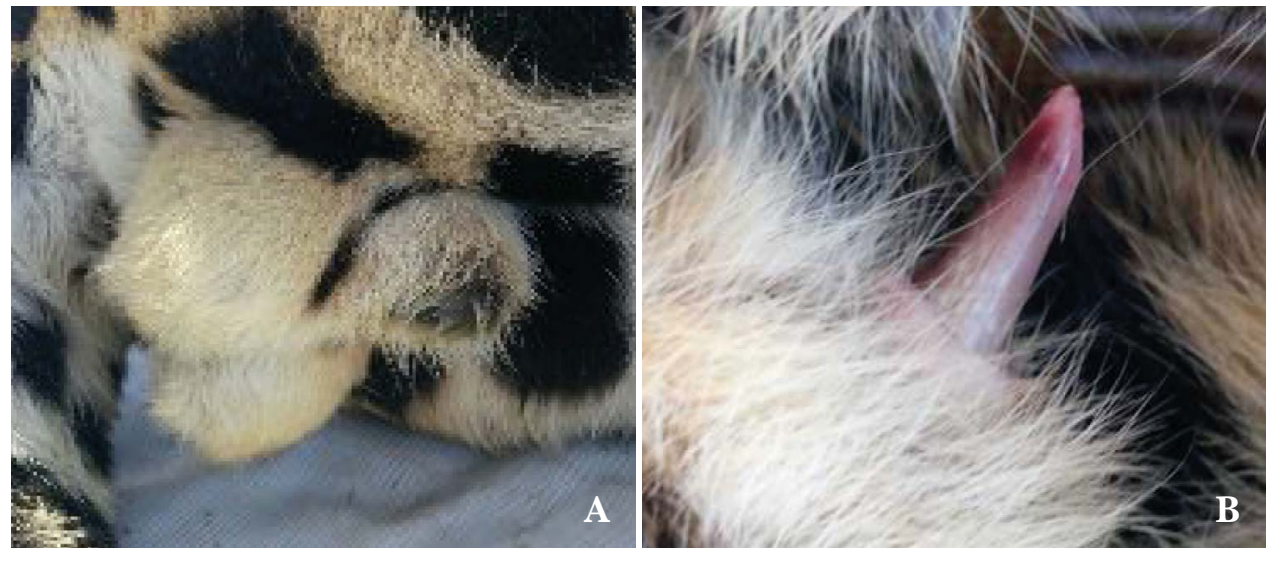

Figure 1. Reproductive apparatus of the jaguar, testicles $(\mathrm{A})$ and penis $(\mathrm{B})$. 
The penis consists of a root, a body and a glans penis, the latter covered by numerous androgen-dependent cornified papillae that appear after puberty. The testes (Figure 2) are in the perineal region with a craniocaudal orientation and formed by testicular tissue, head, body and tail of the epididymis, efferent and deferent ducts, spermatic cord, testicular artery and veins. The head of the epididymis is situated craniolaterally, the body is dorsal and the tail is caudal to the testicles. The vas deferens surround the testis in a cranial direction penetrating the spermatic cord. Attached to the testes are two bulbourethral glands that contribute to the formation of seminal plasma and the prostate, which is formed by a compact and a disseminated portion (Mayor and Lopez, 2010).

\section{Reproductive process}

The jaguar's reproductive process is poorly understood, but it is believed that more than one factor is involved in its regulation, including geographic space, photoperiod, temperature, food availability and psycho-social environment (Figure 3; Feldman and Nelson, 1996).

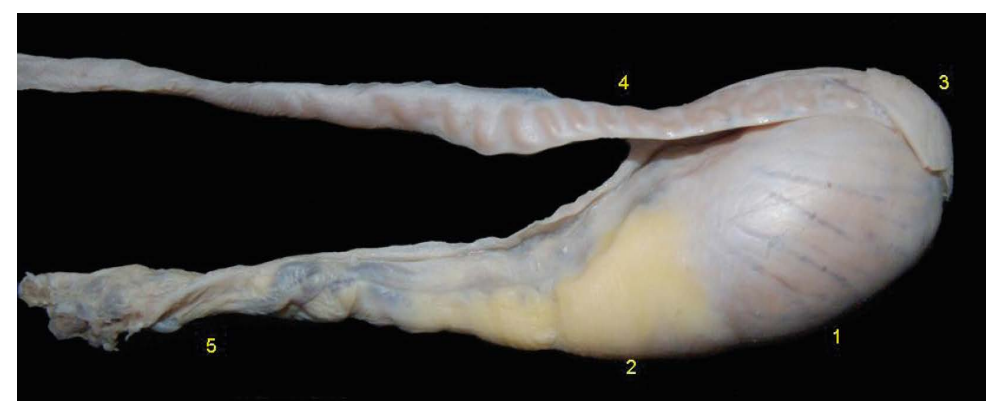

Figure 2. Male gonad showing its parts 1) testicle, 2) head of the epididymis, 3) tail of the epididymis, 4) vas deferens, 5) testicular vessels and nerves. With permission from Mayor and López (2010). Atlas de Anatomía de especies silvestres de la Amazonia peruana.

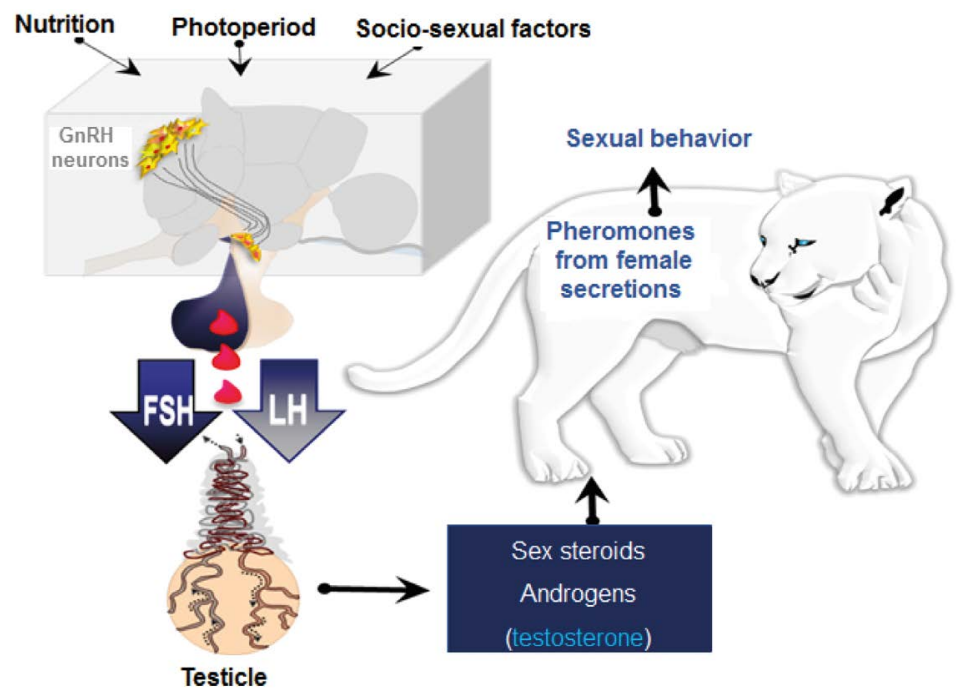

Figure 3. Influence of environmental factors on jaguar reproductive behavior. Pheromones help them to mark territory and avoid the entry of other males, androgens stimulate pheromone production, and secretion is constant or regulated by photoperiod. 
Reproductive hormones. Neuroendocrine interactions between the hypothalamus and pituitary gland control testicular function. GnRH (gonadotropin-releasing hormone), a neurohormone secreted by the preoptic-hypothalamic area (APO-H), stimulates the gonadotropes in the pituitary to secrete LH (luteinizing hormone) and FSH (folliclestimulating hormone). These gonadotropins enter and travel through the bloodstream to reach the testes to directly influence spermatogenesis through their effect on Leydig and Sertoli cells (Figure 4). For example, if the secreted testosterone concentration by Leydig cells is increased in the blood, negative feedback is exerted at the APO-H and pituitary level, inhibiting pulsatile $\mathrm{GnRH} / \mathrm{LH}$ secretion, which decreases the testosterone secretion by Leydig cells. On other hand, FSH directly acts on sperm production, Sertoli cells, in turn, secrete inhibin and activin (Johnston et al., 2001).

Photoperiod effect. Photoperiod also influences males, who show a seasonal variation in androgen levels during the year. An increase in these hormones level seems to be linked both to the increase in prey and to the season in domestic cats (Felis catus), Pallas's cat (Otocolobus manul), snow leopard (Uncia uncia), among others. Swanson and Brown (1996) mentioned that changes in the spermatogenesis relate to the photoperiod; in addition, they indicated that there were variations in the quantity, sperm quality and hormone levels in the blood at different times of the year. Regard the free-living felids, particularly jaguars. Morato et al. (2001) conducted a study on reproductive aspects of this felid in captivity and found an average ejaculate volume of $8.6 \pm 1.3 \mathrm{~mL}(\mathrm{n}=28)$, with a concentration of
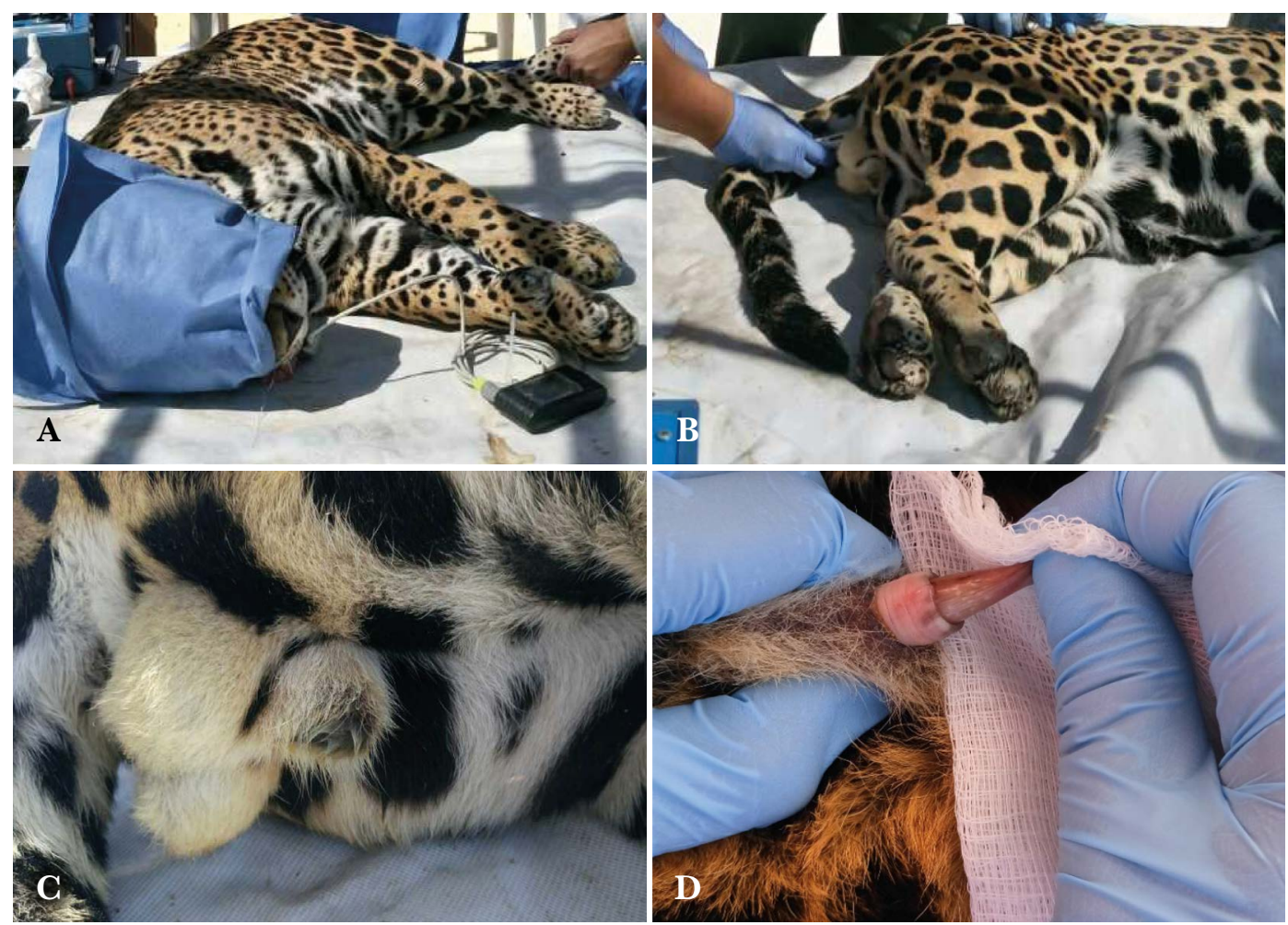

Figure 4. Procedures to be performed before obtaining semen samples in jaguar. A) Anesthetized jaguar. B) Physiological constants check. C) Palpation of the testicles. D) Penile exposure. 
$3.9 \pm 0.7 \times 10^{6}$ spermatozoa per $\mathrm{mL}$. Although there were variations in ejaculate volume during the seasons (autumn $6.0 \pm 0.9 \mathrm{~mL}, 10.9 \pm 4.3 \mathrm{~mL}$ in winter, $9.0 \pm 3.7 \mathrm{~mL}$ in spring and summer $7.9 \pm 0.8 \mathrm{~mL}$ ), there were no seasonal differences. For testosterone, these researchers indicated that there were also no differences due to the sampling season, although there were some numerical variations. For example, during fall, testosterone production was $170 \pm 20.7 \mathrm{ng} \mathrm{dL}{ }^{-1}$, while in winter and spring it was $324 \pm 60.4$ and $287.9 \pm 52.5 \mathrm{ng} \mathrm{dL}^{-1}$, respectively. Regard sperm quality, Morato et al. (1999) mentioned having found a high percentage of sperm malformations (51\%), a large amount of sperm malformations is common in captive felids (Table 1). In the case of the domestic cats and the black-footed cats (Felis nigripes), Herrick et al. (2010) reported higher than 80\% sperm abnormalities.

Spermatogenesis. Spermatogenesis is a sequence of cytological events of male germ cells (multiplication and differentiation) that result in spermatozoa formation. Spermatogenesis takes place cyclically in the epithelium of the seminiferous tubules of the testis, starting at the onset of puberty. At the end of the spermatogenic process, spermatozoa are released into the lumen of the seminiferous tubules and taken to the epididymis, where they complete the maturation process and acquire fertilizing capacity (Gilbert, 2005). The sperm membrane is capable of absorbing different substances produced in the seminiferous tubules, epididymis, vas deferens and accessory sex glands (semen). Another interesting aspect is that, unlike other mammals, feline sperm capacitation is simpler and takes less time (Holstein et al., 2003).

\section{Assisted reproduction techniques}

In Mexico, as in other countries, the jaguar is an endangered species due to its habitat destruction, illegal hunting and prey scarcity (Ceballos, 2010). Therefore, captive reproduction of this feline is an important option for its preservation by properly managing assisted reproduction techniques such as semen freezing, artificial insemination, in vitro fertilization and embryo transfer (Morrell et al., 1998). These techniques can help genetic exchange between populations (Morato et al., 2001), improve reproductive success, reduce aggressive behavior, female-male incompatibility and physical problems, and reduce the transmission of infectious diseases during mating. It is also possible to transfer semen from captive males to free-living females, or between geographically separated wild populations, which contributes to increasing genetic variability (Swanson, 2006; Morato et al., 2001). This can be done with fresh or frozen semen. Therefore, there is a need for genetically characterized specimens, which is not easy to obtain (Morato et al., 2001). According to Paz (2000), in Brazil only 4\% of captive jaguars has reproduced in recent years, possibly due to the difficulty of determining behavior during the estrous cycle, lack of knowledge of the hierarchical structure when kept in the same cage, photoperiod (induced ovulation vs. spontaneous ovulation; Wildt et al., 1995) and perhaps also to nutritional status (undernutrition).

In some countries, assisted reproduction techniques are applied in wild animals based on the pharmacological protocols used in domestic animals, although sometimes it is not 
possible to apply the same protocols from one species to another, due to the differences in their reproductive mechanisms and their behavior.

\section{Semen collection}

Animal handling. The characteristics of wild animals are special, therefore, obtaining semen samples is performed in anesthetized animal (Herrera et al., 2017) with an electroejaculator, whereas in any other medical procedures using anesthetics, it requires to withdrawal water and food from the specimens at least 12 and $24 \mathrm{~h}$, respectively before its application. According to the AZA (2016), the following products can be used 1) Telazol ${ }^{\circledR}$ [4-8 $\mathrm{mg} \mathrm{kg}^{-1}$ IM (intramuscular), Kreeger and Armstrong, 2010], 2) Xylazine ${ }^{\circledR}$ $\left(2 \mathrm{mg} \mathrm{kg}^{-1}\right)$ via IM combined with Ketamine ${ }^{\circledR}$. It is recommended to give Rohimbine ${ }^{\circledR}$ $\left(0.125 \mathrm{mg} \mathrm{kg}^{-1}\right)$ after anesthesia to reverse the Xylazine ${ }^{\circledR}$ effects. Atropine sulfate ${ }^{\circledR}$ $\left(0.04 \mathrm{mg} \mathrm{kg}^{-1}\right)$ or Glycopyrrolate ${ }^{\circledR}\left(0.01-0.02 \mathrm{mg} \mathrm{kg}^{-1}\right)$ can also be administered as a single dose IM or subcutaneously in case, the animal presents excessive salivation. In some cases, anesthesia can cause contamination of the seminal sample with urine, as the bladder relaxes. Therefore, in jaguars, it is recommended to use Zoletil ${ }^{\circledR}, 6-8 \mathrm{mg}$ $\mathrm{kg}^{-1}$ and even supplement it with ketamine. Once the animal is anesthetized (Figure 4), it is advisable to determine their body condition, palpate the testicles and evaluate their consistency (flaccid, normal or turgid) and measure their length and width (Morato et $a l ., 2001)$ to determine the volume. The penis is extruded from the sheath and examined to visualize the presence of cornified papillae (1-3 scale, $3=$ most prominent papillae) as indicated by Swanson et al. (1995).

Sperm samples obtention. It consists in following protocols for collecting and storing by cooling or freezing the sperm samples obtained by electro-ejaculation, epididymal lavage or testicular tissue (Garde et al., 1998), once the sampling is done, the semen is evaluated to determine its macroscopic and microscopic characteristics, deposited in straws and stored in liquid nitrogen tanks for later study or use.

Electroejaculation. It consists of electrical stimulation through a transrectal probe coupled to a voltage unit (Figure 5).

On jaguars, Morato et al. (2001) used a $2.6 \mathrm{~cm}$ diameter probe with a $29 \mathrm{~cm}$ length and a $60 \mathrm{~Hz}$ battery-powered electrostimulation (AC, $60 \mathrm{~Hz}$ ), applying 80 electrical stimuli divided into three series; 30, 30 and 20 stimuli with 10-minute intervals between series.

Sperm recovery from the epididymis. This technique can be used when a genetically valuable animal dies. With this technique, spermatozoa are obtained directly from the tail of the epididymis (Chatdarong et al., 2010). Two techniques can be used for this purpose 1) flotation, which consists of cutting the epididymis into small pieces in a diluent solution for the sperm extraction (Morton et al., 2010); and 2) retrograde lavage which consists of injecting a buffered solution into the vas deferens and then retrieving.

Testicular tissues preservation. Another technique is the preservation of testicular tissue, which represents a challenge for cryobiology; there are predictions that if the testicular tissue retained active spermatogenesis, elongated spermatids could be obtained for oocyte fertilization by using intracytoplasmic sperm injections (Oliveira et al., 2015). On other hand, Abrishami et al. (2010) proposed that testicular freezing can be used in 


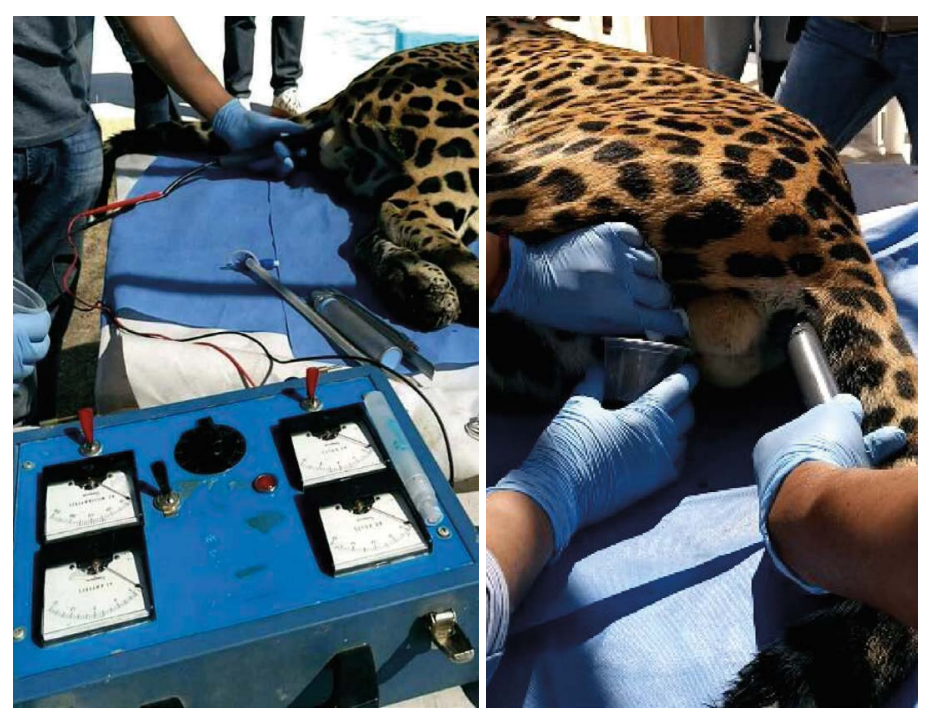

Figure 5. Electro-ejaculation technique applied to a 3-year-old jaguar in captivity.

cases where animals suddenly die. Regard the above, in recent years Campos-Junior et al. (2014) published a successful study in collared peccary.

Sperm evaluation. Once the semen is collected, their evaluated parameters are their total volume $(\mathrm{mL}), \mathrm{pH}$, sperm count $\left(\times 10^{6}\right)$, motility $(0-100 \%)$, advancement on a scale of 0 to $5(0=$ no movement and $5=$ rapid forward movement; Wildt et al., 1983), sperm concentration, normal or abnormal classification (Josthon et al., 1994; Morato et al., 2001) and acrosomal integrity (Yanagimachi, 1994). Some data on sperm evaluation are shown in Table 1, where some differences in reproductive parameters measured in captive and free-living jaguars can be observed, as well as the high percentage of abnormal sperm cells found.

Sperm conservation. Techniques and protocols in semen preservation should focus on the specific characteristics of each species, given the differences in the physiology during sperm production and the inherent changes in the preservation process to which the spermatozoa are subjected. How the semen is evaluated, its type of packaging (straws), the composition of the extender (diluters), duration of equilibration time, freezing curve, storage and thawing speed are determining factors for success in the conservation of male gametes from wild felines (Roldan, 2010).

Table 1. Testicular, seminal and hormonal characteristics in jaguar males.

\begin{tabular}{|c|c|c|c|c|c|c|c|c|}
\hline Species & Weight (kg) & $\mathrm{TV}\left(\mathrm{cm}^{3}\right)$ & Vol (mL) & $\mathrm{C}\left(\times 10^{6} / \mathrm{mL}^{-1}\right)$ & $\mathbf{A}(\%)$ & $\mathbf{M}(\mathbf{I})(\%)$ & ST $\left(\right.$ ng mL $\left.\mathbf{~ m}^{-1}\right)$ & Author \\
\hline Captive Jaguar & & $45.3 \pm 3.9$ & $8.6 \pm 1.3$ & $3.9 \pm 0.7 * *$ & 51.0 & $50.6 \pm 5.8$ & $114-445^{* * * *}$ & Morato et al. (1999) \\
\hline Free Jaguar & $96.0 \pm 7.7$ & $52.4 \pm 3.4$ & $4.1 \pm 0.7$ & $35.0 \pm 21.3$ & 26.5 & $73.0 \pm 6.1$ & $2.1 \pm 0.8$ & Morato et al. (2001) \\
\hline Captive Jaguar & $72.0 \pm 11.0$ & $41.6 \pm 0.6$ & $8.3 \pm 0.7$ & $8.0 \pm 1.7$ & 50.0 & $64.0 \pm 2.4$ & $3.1 \pm 0.7$ & Morato et al. (2001) \\
\hline Captive Jaguar & $83.1 \pm 20.3$ & $\mathrm{ND}$ & ND & ND & $\mathrm{ND}$ & $32 \pm 24.3^{*}$ & $\mathrm{ND}$ & $\begin{array}{l}\text { Gaviria-Sciolle y } \\
\text { Arias-Bernal }(2011)\end{array}$ \\
\hline
\end{tabular}

$\mathrm{VT}=$ Testicular volume, $\mathrm{C}=$ Concentration, $\mathrm{A}=$ abnormalities, $\mathrm{M}=$ motility, $\mathrm{I}=$ index. $*$ Progressive motility after semen thawing at $37^{\circ} \mathrm{C}$, ** $\times$ $10^{6} / \mathrm{mL}, \mathrm{ST}=$ Serum testosterone, ${ }^{* * *}(\mathrm{ng} / \mathrm{dL}) . \mathrm{ND}=$ Not determined in the works cited. 


\section{Artificial insemination}

It is a technique used to deposit spermatozoa in the female reproductive tract at the "right" time to achieve oocyte fertilization. Despite its popularity in animals of zootechnical interest, it is rarely used in reproductive programs of free-living animals due to the scarce knowledge of the female's reproductive physiology (Roldan, 2010). Despite this, they have been able to obtain offspring in ocelot females by laparoscopy (Swanson et al., 1995) and in puma, tiger, cheetah, clouded panther, snow leopard, ocelot and margay females with artificial insemination using fresh semen (Roldan, 2010).

\section{In vitro fertilization and sperm microinjection}

These techniques can be used when the quantity or quality of spermatozoa is reduced or in cases where the sperm do not survive the freezing process. In the case of in vitro fertilization, it is recommended that the conditions are like those in the genital tract, although further research is required (Roldán, 2010).

\section{CONGLUSIONS}

Advances in assisted reproductive techniques involving male jaguars were presented. However, the necessity of specific protocols for seminal conservation and its possible use in in vitro fertilization and artificial insemination is made evident.

\section{REFERENCES}

Abrishami, M., Anzar, M., Yang, Y., Honaramooz A. (2010). Cryopreservation of immature porcine testis tissue to maintain its developmental potential after xenografting into recipient mice. Theriogenology 73 (1), 86-96. Doi: 10.1016/j.theriogenology.2009.08.004

AZA. (2016) Plan de Supervivencia de Especies de Jaguar de la AZA. Manual para cuidado de jaguares (Panthera onca). Asociación de Zoológicos y Acuarios. Silver Spring, MD. USA.

Campos-Junior, P.H.A., Costa, G.M.J., Avelar, G.F., Lacerda, S.M.S.N., Costa, N.N., Orashi, O.M., França, L.R. (2014). Derivation of sperm from xenografted testis cells and tissues of the peccary (Tayassu tajacu). Reproduction, 147,(3). 291-299. Doi: 10.1530/REP-13-0581

Ceballos, G., Oliva G. (2005). Los mamiferos silvestres de México. Comisión Nacional para el Conocimiento y Uso de la Biodiversidad, Fondo de Cultura Económica, México D. F., México.

Ceballos, G. (2010). El Jaguar. Señor de las selvas. En G. Ceballos, R. List, R. Medellín, C. Bonacic, y J. Pacheco. (Eds.). Los felinos de América. Cazadores Sorprendentes (pp. 47-95). Mexico, D. F., México, editorial Grupo Cars.

Ceballos, G., Chávez C., List, R., Zarza H., Medellín, R. A. (Eds.). (2011). Jaguar Conservation and Management in México: Case Studies and Perspectives. México. Alianza wwF/Telcel-Universidad Nacional Autónoma de México.

Chatdarong, K., Thuwanut, P., Morrell, J.M. (2010). Single-layer centrifugation through colloid selects improved quality of epididymal cat sperm. Theriogenology, 73,(9). 1284-1292. Doi: 10.1016/j. theriogenology.2009.12.009

Feldman, E.G., Nelson, R.W. (1996). Canine and feline endocrinology and reproduction. Philadelphia: W.B Saunders Co.

Garde, J.J., Ortiz, N., García, A.J., López, A., Gallego, L. (1998). Criopreservation of sperm samples collected postmortem and artificial insemination in Iberian deer. Archivos de Zootecnia, 47, 351-356.

Gaviria-Scioville, M. T., Arias-Bernal, L. (Julio de 2011). Sinopsis sobre la obtención, evaluación y criopreservación de semen de jaguar (Phantera onca) en cautiverio en cuatro zoológicos colombianos. En D. S. Tovar (Presidencia) Memorias de la conferencia interna en Medicina y Aprovechamiento de Fauna Silvestre, Exótica y no Convencional. Conferencia llevada a cabo en Bogotá, Colombia.

Gilbert, F.S. (2005). Biología del Desarrollo, Buenos Aires, Argentina: Editorial Médica Panamericana.

Herrera, B. J. A., Landa, G. S. S., González, S. J. A., Camarillo, F. R., \& Gual, S.F. (2017). Métodos para la contención de felinos silvestres en cautiverio. No 55. CBS. Universidad Autónoma Metropolitana-X. ISBN: 978-607-28-1297-0. 
Herrick, J.R., Campbell, M., Levens, G. (2010). In vitro fertilization and sperm cryopreservation in the blackfooted cat (Felis nigripes) and sand cat (Felis margarita). Biology of Reproduction, 82(3), 552-562. Doi: 10.1095/biolreprod.109.081034

Holstein, F.A., Schulze, W., Davidoff, M. (2003). Understanding spermatogenesis is a prerequisite for treatment. Reproductive Biology Endocrinology, 1(107), 1-16.

Johnston, D.J., Kuztritz, M.V.R., Olson, P. (2001). Canine and feline theriogenology. Philadelphia, USA: WB Saunders.

Kreeger, T. J., Armstrong, D. L. (2010). Tigers and Telazol ${ }^{\circledR}$ : the unintended evolution of caution to contraindication. The Journal of Wildlife Management, 74(6), 1183-1185. Doi: 10.1111/j.1937-2817.2010. tb01238.x

Mayor, P., López, C. (2010). Atlas de Anatomía de especies silvestres de la Amazonía. Disponible en: http:// atlasanatomiaamazonia.uab.cat

Morato, R.G., Conforti, V.A., Azevedo, F.G. (2001). Comparative analyses of semen and endocrine characteristics of free-living versus captive jaguars (Panthera onca). Reproduction (Cambridge, England), 122(5), 745-751. Doi: 10.1530/rep.0.1220745

Morato, R G., Guimarães, M.A.B.V., Ferreira, F., Verreschi, N.L.T., Barnabe, R.C. (1999). Reproductive Characteristics of captive male jaguars (Phantera onca). Brazilian Journal of Veterinary Research and Animal Science, 36(5), 262-266.

Morrell, J.M., Nubbemeyer, R., Heistermann, M., Rosenbusch, J., Küderling I., Holt W., Hodges, J.K. (1998). Artificial insemination in Callithrix jacchus using fresh or cryopreserved sperm. Animal Reproduction Science, 52(2): 165-174. Doi: 10.1016/s0378-4320(97)00092-4

Morton, K., Evans, G., Maxwell, W. (2010). Effect of glycerol concentration, Equex STM ${ }^{\circledR}$ supplementation and liquid storage prior to freezing on the motility and acrosome integrity of frozen-thawed epididymal alpaca (Vicugna pacos) sperm. Theriogenology, 74(2), 311-316. Doi: 10.1016/j.theriogenology.2010.02.015

Oliveira, K.G., Leão, D.L., Almeida, D.V., Santos, R.R., Domingues, S.F. (2015). Seminal characteristics and cryopreservation of sperm from the squirrel monkey, Saimiri collinsi. Theriogenology, 84,(5). 743-749. Doi: 10.1016/j.theriogenology.2015.04.031

Paz, R.G.R. (2000). Influência nutricional sobre a produção e qualidade do sêmen de onças pintadas (Panthera onca) mantidas em cativeiro. [Master's Thesis. Universidade de São Paulo, São Paulo, Brazil].

PROFEPA. (2016). NORMA Oficial Mexicana NOM-059-SEMARNAT-2010, Protección ambiental-Especies nativas de México de flora y fauna silvestres-Categorías de riesgo y especificaciones para su inclusión, exclusión o cambio-Lista de especies en riesgo. Disponible en: https://www.gob.mx/profepa/documentos/norma-oficial-mexicananom-059-semarnat-2010

Roldan, S.E.R.S. (2010). Biología de la reproducción de mamíferos en peligro de extinción. REDVET. Revista electrónica de Veterinaria, 17(7), 1-25.

Swanson, W.F., Horohov, D.W., Godke, R.A. (1995). Production of exogenous gonadotropin-neutralizing immunoglobulins in cats following repeated eCG/hCG treatment and relevance for assisted reproduction in felids. Journal of Reproduction and Fertility, 105, (1).35-41. Doi: 10.1530/jrf.0.1050035

Swanson, W., Brown, J. (1996). Influence of seasonality on reproductive traits of the male Pallas' cat (Felis manul) and implications for captive management. Journal of Zoo and Wildlife Medicine, 27(2), 234-240.

Swanson, W.F. (2006). Application of assisted reproduction for population management in felids: the potential and reality for conservation of small cats. Theriogenology, 66, 49-58.

Wildt, D., Pukazhenthi, B., Brown, J. (1995). Spermatology for understanding, managing and conserving rare species. Reproduction, Fertility, and Development, 7(4), 811-824. Doi: 10.1071/rd9950811

Wildt, D.E., Bush, M., Howard, J.G., O’Brien, S.J., Meltzer D., Van Dyk A., Brand, D.J. (1983). Unique seminal quality in the South African cheetah and a comparative evaluation in the domestic cat. Biology of Reproduction, 29, 1019-1025.

Yanagimachi, R. (1994). Fertility of mammalian spermatozoa: its development and relativity. Zygote, 2 (4). 371-372. 